\title{
ADDITION OF A MAST CELL STABILIZING COMPOUND TO ORGAN PRESERVATION SOLUTIONS DECREASES LUNG REPERFUSION INJURY
}

Mark L. Barr, MD

Joseph N. Carey, BS

Garabed P. Nishanian, MD

Randall F. Roberts, MD

Yasushi Sakamaki, MD

Sevak H. Darbinian, MD

Vaughn A. Starnes, MD
Objective: Research in lung transplant preservation has generally focused on free radicals and enzyme release from neutrophils, parenchymal cells, macrophages, and endothelium. The lung has a large resident population of mast cells that, when activated, release potent inflammatory mediators. We hypothesized that adding an inhibitor of mast cell degranulation, lodoxamide tromethamine (10 $\mu \mathrm{mol} / \mathrm{L})$, to Euro-Collins and University of Wisconsin preservation solutions, would decrease lung preservation injury. Methods: Rat lungs were isolated, flushed with the respective solution, and stored at $4^{\circ} \mathrm{C}$ for 6 or 12 hours. The lungs were reperfused with fresh blood and ventilated with $100 \%$ oxygen. Alveolar-arterial oxygen difference, oxygen tension, capillary filtration coefficient, and compliance were determined. Results: After 6 hours of ischemic storage: lodoxamide tromethamine-enhanced Euro-Collins solution decreased alveolar-arterial oxygen difference from 539 to $457(p=\mathbf{0 . 0 0 4})$, increased oxygen tension from 119 to $205 \mathrm{~mm} \mathrm{Hg}(p=0.006)$, and decreased capillary filtration coefficient from 3.9 to 2.0 ( $p<0.001)$; lodoxamide tromethamine-enhanced University of Wisconsin solution decreased alveolar-arterial oxygen difference from 546 to 317 ( $p<0.001)$, increased oxygen tension from 166 to $335 \mathrm{~mm} \mathrm{Hg}$ $(p<0.001)$, and decreased capillary filtration coefficient from 3.0 to 1.7 $(p<0.001)$. After 12 hours of ischemic storage, lodoxamide tromethamineenhanced Euro-Collins solution decreased alveolar-arterial oxygen difference from 588 to 485 ( $p<0.001$ ), increased oxygen tension from 100 to 161 $\mathrm{mm} \mathrm{Hg}(\boldsymbol{p}=\mathbf{0 . 0 1 2})$, decreased capillary filtration coefficient from 6.2 to 2.6 $(p<0.001)$, and increased compliance from 0.12 to $0.21(p<0.001)$; lodoxamide tromethamine-enhanced University of Wisconsin solution decreased alveolar-arterial oxygen difference from 478 to $322(p<0.001)$, increased oxygen tension from 214 to $335 \mathrm{~mm} \mathrm{Hg}(p<0.001)$, decreased capillary filtration constant from 4.2 to $2.0(p<0.001)$, and increased compliance from 0.20 to $0.25(p<0.001)$. Conclusions: Addition of lodoxamide tromethamine to Euro-Collins or University of Wisconsin solution results in a marked decrease in lung reperfusion injury as demonstrated by increased oxygenation, decreased microvascular permeability, and increased compliance. These results are relevant as Euro-Collins and University of Wisconsin solutions are the most common clinically used lung preservation solutions. This study also highlights the deleterious role of resident mast cells in preservation injury. (J Thorac Cardiovasc Surg 1998; 115:631-7)
From the Division of Cardiothoracic Surgery, Department of Surgery, University of Southern California School of Medicine, Los Angeles, Calif.

This work was supported by a grant (M.L.B.) from the Heart and Lung Surgery Foundation, Los Angeles, Calif.

Read at the Twenty-third Annual Meeting of The Western Thoracic Surgical Association, Napa, Calif., June 25-28, 1997.
Received for publication July 8, 1997; revisions requested Oct. 6, 1997; revisions received Oct. 22, 1997; accepted for publication Oct. 22, 1997.

Address for reprints: Mark L. Barr, MD, Division of Cardiothoracic Surgery, University of Southern California, 1510 San Pablo St., Los Angeles, CA 90033.

Copyright (C) 1998 by Mosby, Inc.

$0022-5223 / 98 \$ 5.00+0 \quad \mathbf{1 2 / 6 / 8 7 2 2 5}$ 
$\mathrm{R}$ esearch in pulmonary transplant preservation has generally focused on understanding and preventing ischemia-reperfusion injury. The deleterious effects of oxygen-derived free radical formation, neutrophil infiltration, and cellular protease release have been extensively investigated and are considered to be the primary mediators of ischemiareperfusion injury. Although lung preservation techniques have benefited from information regarding these pathophysiologic mechanisms, the problem of reperfusion injury, experimentally and clinically, continues to result in unpredictable graft function, and other mechanisms of injury have been suggested. ${ }^{1}$ Mast cells can be activated by ischemia and reperfusion, ${ }^{2,3}$ and they release thromboxanes, platelet-activating factor, histamine, prostaglandins, and leukotrienes. These substances cause smooth muscle contraction, increased vascular permeability, and neutrophil chemotaxis, all of which may adversely affect lung function after transplantation. Human lungs have an inherent population of mast cells (approximately 500 to $4000 / \mathrm{mm}^{3}$ ), which reside in the perivascular, peribronchiolar, and bronchoalveolar spaces.

Lodoxamide tromethamine (LT) is a derivative of the anti-allergy drug cromolyn sodium (INN: cromoglicic acid) and inhibits mast cell degranulation in vitro and in vivo. ${ }^{4}$ The drug was originally developed for prophylaxis of mast cell-mediated asthma. It has the additional effects of being a hydroxyl radical scavenger ${ }^{5}$ and an inhibitor of xanthine oxidase $^{6}$ and neutrophil chemotaxis. ${ }^{7}$ On the basis of these properties, LT has been used experimentally to decrease ischemia-reperfusion injury in car$\operatorname{diac}^{8}$ and spinal cord ${ }^{9}$ models. Previous studies have used high-dose LT to prevent pulmonary ischemiareperfusion injury by inhibiting xanthine oxidase. ${ }^{10}$ In an isolated, crystalloid-perfused rat heart model, we had previously demonstrated that a lower dose of LT could reduce cardiac mast cell degranulation and reduce myocardial dysfunction after hypoxia and reoxygenation. ${ }^{11}$ On the basis of the significantly higher density of mast cells in the lungs, we hypothesized that adding a mast cell-inhibiting dose of LT to the most commonly used lung preservation solutions, Euro-Collins (EC) and University of Wisconsin (UW) solutions, would decrease ischemiareperfusion injury and improve pulmonary preservation after prolonged ischemic storage. We evaluated this hypothesis in an isolated, bloodperfused rat lung model in which physiologic param- eters, as well as experimental measurements of capillary permeability, could be assessed.

\section{Methods}

All animals received humane care according to the "Principles of Laboratory Animal Care," formulated by the National Society for Medical Research, and the "Guide for the Care and Use of Laboratory Animals," prepared by the National Academy of Sciences and published by the National Institutes of Health (NIH publication No. 86-23, revised 1985).

\section{Donor procedures}

Lungs. Male Lewis rats (250 to $350 \mathrm{gm}$ ) were anesthetized (sodium pentobarbital, $50 \mathrm{mg} / \mathrm{kg}$, intraperitoneally) and tracheostomized with a stopcocked 14-gauge angiocatheter. A rodent ventilator (Harvard Apparatus Company, S. Natick, Mass.) was used to maintain normal respiration (respiratory rate, 50/min; tidal volume, 10 $\mathrm{ml} / \mathrm{kg}$; positive end-expiratory pressure, $2 \mathrm{~cm} \mathrm{H}_{2} \mathrm{O}$; room air). A median sternotomy and thymectomy were performed, the thoracic organs exposed, and the inferior pulmonary ligaments divided. Heparin $(1000 \mathrm{U})$ was then injected via the inferior vena cava. The inferior and superior venae cavae were ligated and divided, and the apex of the heart was amputated. The lungs were flushed via the main pulmonary artery with cold preservation solution $\left(4^{\circ} \mathrm{C} ; 50 \mathrm{ml} / \mathrm{kg}\right)$ from a height of $30 \mathrm{~cm}$. On completion of the flush, the tracheal catheter was occluded to maintain lung inflation, and the donor heart and lungs were removed en bloc, suspended from a support rod in the esophagus, and secured to the tracheal catheter and stopcock with 3-0 ligatures. The heart-lung block was immediately submerged in the corresponding preservation solution-filled plastic container, covered with plastic wrap, and maintained at $4^{\circ} \mathrm{C}$ for the remainder of the ischemic storage period.

Blood. Male Lewis rats were placed under surgical anesthesia as previously described. A sternotomy and laparotomy were performed and heparin (1000 U) was injected via the inferior vena cava. Blood was obtained via a subdiaphragmatic inferior vena caval puncture and the animal was put to death with pentobarbital $(100 \mathrm{mg} / \mathrm{kg}$, intraperitoneally).

\section{Reperfusion and monitoring}

Reperfusion. After the designated storage period, the pulmonary artery and the left atrium were cannulated with 14-gauge angiocatheters via the right and left ventricles, respectively, and the catheters were secured with 8-0 ligatures. The cannulated block was then suspended from a force transducer via the esophagus, placed in a humidified, temperature-controlled $\left(37^{\circ} \mathrm{C}\right)$ chamber, and ventilated with $100 \%$ oxygen according to the previously described ventilatory parameters. Reperfusion was initiated by connecting the pulmonary artery cannula to a reservoir containing the previously obtained fresh syngeneic venous blood, suspended from a height that generated $15 \mathrm{~mm} \mathrm{Hg}$ of pressure. The left atrial cannula was then connected to a separate reservoir, and the heights of the two reservoirs were adjusted to produce an isogravimetric state (state of no net weight gain) at which the lungs were maintained for 5 minutes. At the end of the 
5-minute isogravimetric equilibration period, the capillary pressure was increased $10 \mathrm{~mm} \mathrm{Hg}$ by raising the heights of the pulmonary artery and left atrial reservoirs, and the resulting pressure was maintained for 15 minutes.

Monitoring. Throughout the reperfusion period, specimen weight (FT 03 force-displacement transducer, Grass Instruments, Inc., Quincy, Mass.), inflow pressure and outflow pressure (DTX model T4812 AD-R pressure transducer, Viggo-Spectramed, Oxnard, Calif.), tracheal pressure (Validyne DP 45-24 differential pressure transducer, Validyne Engineering Corp., Northridge, Calif.), and tidal volume (Fleisch No. 2 pneumotachograph, Whittaker Medical Manufacturing, Richmond, Va.; Validyne DP 45-14 pressure transducer) were measured. All data were transmitted to an AST Bravo IBM-compatible computer via a Validyne CD 280 and MC 1-3 carrier demodulator and a Dash 16 A/D converter (Validyne), and processed and displayed by a customized version of Microsoft Visual Basic Pro software (Microsoft Corporation, Redmond, Wash.). With an analysis and computation time of 10 seconds, six recordings per 1 minute of data flow were performed.

Experimental protocol. Isolated lungs were flushed with either modified EC solution (Euro-Collins solution, Baxter Healthcare Products, Deerfield, Ill.; modified with $2.5 \mathrm{ml} \mathrm{50 \%} \mathrm{magnesium} \mathrm{sulfate} \mathrm{and} 50 \mathrm{ml} 50 \%$ dextrose per liter) or UW solution (Viaspan, DuPont Merck Pharmaceutical, Wilmington, Del., with $40 \mathrm{U}$ insulin and $16 \mathrm{mg}$ dexamethasone per liter) and stored in the same solution for 6 or 12 hours. Control lungs were flushed and stored using standard solution, and experimental lungs were flushed and stored using solution with $10 \mu \mathrm{mol} / \mathrm{L}$ of LT. At each storage time there were two experimental and two control groups consisting of six lungs each: standard EC, standard UW, EC+LT $(\mathrm{EC}+\mathrm{L})$, and $\mathrm{UW}+\mathrm{LT}(\mathrm{UW}+\mathrm{L})$.

Data analysis

Determination of the capillary filtration coefficient (Kf). The calculation of the capillary filtration coefficient $(\mathrm{Kf})$ has been previously described in detail. ${ }^{12}$ In brief, Kf was assessed by increasing pulmonary capillary pressure 10 $\mathrm{mm} \mathrm{Hg}$ from an initial isogravimetric state and measuring the rate of weight gain caused by edema formation. Three minutes were allowed before Kf measurement for completion of rapid weight gain resulting from vascular filling and distention. The rate of slow weight gain that occurred during minutes 3 to 8 was plotted semilogarithmically and extrapolated back to time zero (when the capillary pressure was initially raised). The time zero filtration rate was divided by the change in capillary pressure and normalized to $100 \mathrm{gm}$ wet lung weight to express $\mathrm{Kf}$ in milliliters per minute per millimeters of mercury per $100 \mathrm{gm}$.

Blood gas analysis. A blood sample from the left atrium was collected at the end of the reperfusion period to assess the gas exchange capability of the lungs. Samples were analyzed with a Ciba Corning 288 blood gas and electrolyte analyzer (Ciba Corning, Medfield, Mass.). Measured values of oxygen tension $\left(\mathrm{PO}_{2}\right)$ and a calculated alveolar-arterial oxygen difference $\left(\mathrm{A}-\mathrm{aDO}_{2}\right)$ were recorded.

Compliance. Recorded tidal volume/airway pressure values were measured every 10 seconds and averaged over

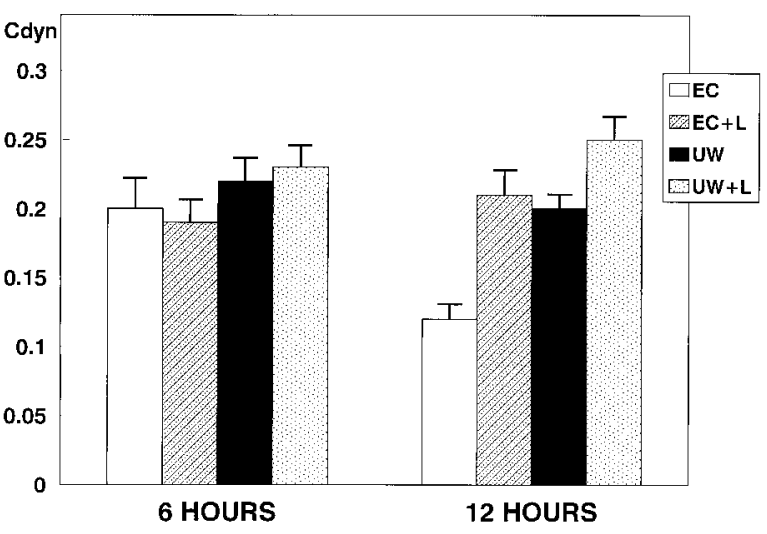

Fig. 1. Compliance for all groups at 6 and 12 hours of storage. Compliance was measured as tidal volume/airway pressure and expressed in milliliters per centimeter of water. The only significant comparison at the 6-hour storage time was $\mathrm{UW}+\mathrm{L}$ versus $\mathrm{EC}+\mathrm{L}, p=0.008$. Significant comparisons at the 12-hour storage time were as follows: $\mathrm{EC}+\mathrm{L}$ versus $\mathrm{EC}, p<0.001 ; \mathrm{UW}+\mathrm{L}$ versus $\mathrm{UW}, p<0.001 ; \mathrm{UW}+\mathrm{L}$ versus $\mathrm{EC}+\mathrm{L}, p=0.008$; $\mathrm{UW}$ versus $\mathrm{EC}, p<0.001$.

the 5-minute isogravimetric period to assess lung compliance.

Statistics. All data were compared by one-way analysis of variance with Student-Newman-Keuls post-test. All data are expressed as mean \pm standard deviation.

\section{Results}

Compliance (Fig. 1). Higher compliance values correspond with better lung function. Compliance values were significantly higher in the $\mathrm{UW}+\mathrm{L}$ and $\mathrm{EC}+\mathrm{L}$ groups than in the UW and $\mathrm{EC}$ groups after 12 hours of ischemic storage: $\mathrm{EC}+\mathrm{L}(0.21 \pm 0.02)$ versus EC $(0.12 \pm 0.01), p<0.001 ; \mathrm{UW}+\mathrm{L}(0.25 \pm$ $0.02)$ versus UW $(0.20 \pm 0.01), p<0.001$. Compliance values were significantly higher for the $\mathrm{UW}+\mathrm{L}$ group when compared with the $\mathrm{EC}+\mathrm{L}$ group for both storage times: for 6 hours, UW $+\mathrm{L}(0.23 \pm$ $0.02)$ versus $\mathrm{EC}+\mathrm{L}(0.19 \pm 0.02), p=0.008$; for 12 hours, $\mathrm{UW}+\mathrm{L}(0.25 \pm 0.02)$ versus $\mathrm{EC}+\mathrm{L}(0.21 \pm$ $0.02), p=0.008$. Compliance values were significantly higher for the UW group than for the EC group at the 12-hour storage time: UW (0.20 \pm $0.01)$ versus $\mathrm{EC}(0.12 \pm 0.01), p<0.001$.

$\mathrm{A}^{-\mathbf{a D o}_{2}}$ (Fig. 2). Lower A-aDO $\mathrm{O}_{2}$ values correspond with improved gas exchange capability. At both storage times, $\mathrm{A}-\mathrm{aDO}_{2}$ values were significantly lower in the $\mathrm{UW}+\mathrm{L}$ and $\mathrm{EC}+\mathrm{L}$ groups when compared with the UW and EC groups: for 6 hours, $\mathrm{EC}+\mathrm{L}$ $(457 \pm 2)$ versus EC $(539 \pm 22), p=0.004 ; \mathrm{UW}+\mathrm{L}$ 


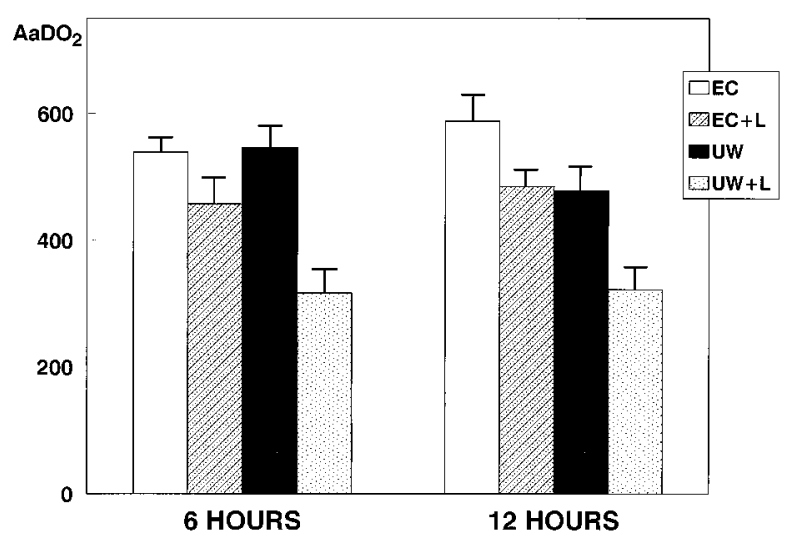

Fig. 2. A-aDo2 (in millimeters of mercury) for all groups at 6 and 12 hours of storage. Significant comparisons at 6 hours of storage were as follows: $\mathrm{EC}+\mathrm{L}$ versus $\mathrm{EC}, p=$ 0.004; $\mathrm{UW}+\mathrm{L}$ versus $\mathrm{UW}, p<0.001 ; \mathrm{UW}+\mathrm{L}$ versus $\mathrm{EC}+\mathrm{L}, p<0.001$. Significant comparisons at 12 hours of storage were as follows: $\mathrm{EC}+\mathrm{L}$ versus $\mathrm{EC}, p<0.001$; $\mathrm{UW}+\mathrm{L}$ versus $\mathrm{UW}, p<0.001 ; \mathrm{UW}+\mathrm{L}$ versus $\mathrm{EC}+\mathrm{L}, p<$ 0.001 ; UW versus EC, $p<0.001$.

$(317 \pm 36)$ versus $\mathrm{UW}(546 \pm 38), p<0.001$; for 12 hours, $\mathrm{EC}+\mathrm{L}(485 \pm 46)$ versus $\mathrm{EC}(588 \pm 26), p<$ $0.001 ; \mathrm{UW}+\mathrm{L}(322 \pm 51)$ versus $\mathrm{UW}(478 \pm 40)$, $p<0.001 . \mathrm{A}-\mathrm{aDO}_{2}$ values were significantly lower for the $\mathrm{UW}+\mathrm{L}$ group than for the $\mathrm{EC}+\mathrm{L}$ group at both storage times: for 6 hours, $\mathrm{UW}+\mathrm{L}(317 \pm 36)$ versus $\mathrm{EC}+\mathrm{L}(457 \pm 42), p<0.001$; for 12 hours, $\mathrm{UW}+\mathrm{L}$ $(322 \pm 51)$ versus $\mathrm{EC}+\mathrm{L}(485 \pm 46), p<0.001$. $\mathrm{A}-\mathrm{aDO}_{2}$ values were significantly lower for the UW group than for the EC group at the 12-hour storage time: UW $(478 \pm 40)$ versus EC $(588 \pm 26), p<$ 0.001 .

$\mathrm{Po}_{2}$ (Fig. 3). Higher $\mathrm{PO}_{2}$ in left atrial pulmonary outflow blood samples indicated improved oxygenation ability. At both storage times $\mathrm{PO}_{2}$ values were significantly higher for the $\mathrm{UW}+\mathrm{L}$ and $\mathrm{EC}+\mathrm{L}$ groups when compared with the $\mathrm{EC}$ and $\mathrm{UW}$ groups: for 6 hours, $\mathrm{EC}+\mathrm{L}(205 \pm 51)$ versus EC $(119 \pm 23), p=0.006$; $\mathrm{UW}+\mathrm{L}(335 \pm 50)$ versus UW (166 \pm 57$), p<0.001$; for 12 hours, $\mathrm{EC}+\mathrm{L}$ $(161 \pm 22)$ versus EC $(100 \pm 35), p=0.012 ; \mathrm{UW}+\mathrm{L}$ $(335 \pm 49)$ versus UW $(214 \pm 30), p<0.001 . \mathrm{Po}_{2}$ values were significantly higher for the $\mathrm{UW}+\mathrm{L}$ group than for the $\mathrm{EC}+\mathrm{L}$ group at both storage times: for 6 hours, $\mathrm{UW}+\mathrm{L}(335 \pm 50)$ versus $\mathrm{EC}+\mathrm{L}$ (205 \pm 51$), p<0.001$; for 12 hours, $\mathrm{UW}+\mathrm{L}(335 \pm$ $49)$ versus $\mathrm{EC}+\mathrm{L}(161 \pm 22), p<0.001 . \mathrm{Po}_{2}$ values were significantly higher for the UW group than for

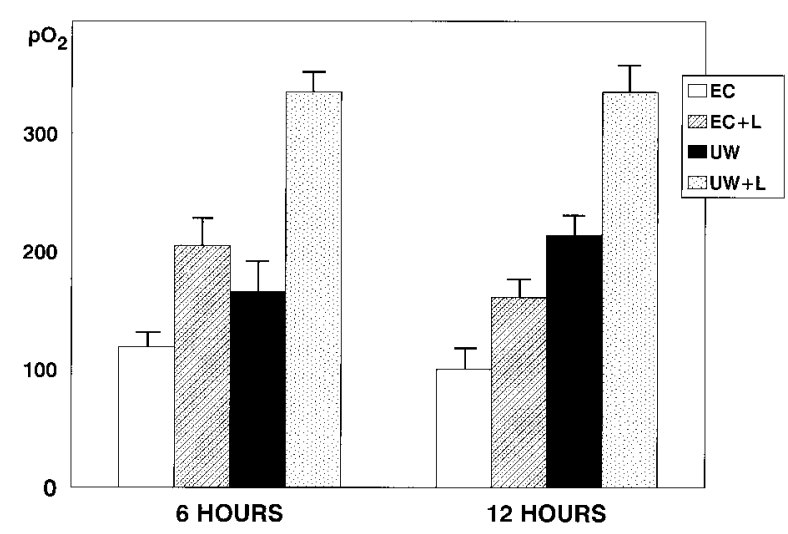

Fig. 3. $\mathrm{Po}_{2}$ in millimeters of mercury for all groups at 6 and 12 hours of storage. Significant comparisons at 6 hours of storage were as follows: $\mathrm{EC}+\mathrm{L}$ versus $\mathrm{EC}, p=$ $0.006 ; \mathrm{UW}+\mathrm{L}$ versus $\mathrm{UW}, p<0.001 ; \mathrm{UW}+\mathrm{L}$ versus $\mathrm{EC}+\mathrm{L}, p<0.001$. Significant comparisons at 12 hours were as follows: $\mathrm{EC}+\mathrm{L}$ versus $\mathrm{EC}, p=0.012 ; \mathrm{UW}+\mathrm{L}$ versus $\mathrm{UW}, p<0.001$; $\mathrm{UW}+\mathrm{L}$ versus $\mathrm{EC}+\mathrm{L}, p<0.001$; $\mathrm{UW}$ versus $\mathrm{EC}, p<0.001$.

the EC group at the 12-hour storage time: UW $(214 \pm 30)$ versus EC $(100 \pm 35), \mathrm{p}<0.001$.

Kf (Fig. 4). The value of Kf for a given lung specimen reflects the rate of edema formation across the microvascular membranes and is a sensitive experimental measurement of lung injury. Decreased $\mathrm{Kf}$ values correspond to improved membrane integrity with decreased capillary permeability and decreased impairment of lung function. At both storage times, Kf values were significantly lower for the $\mathrm{UW}+\mathrm{L}$ and $\mathrm{EC}+\mathrm{L}$ groups than for the $\mathrm{UW}$ and EC groups: for 6 hours, $\mathrm{EC}+\mathrm{L}(2.0 \pm 0.30)$ versus $\mathrm{EC}(3.9 \pm 0.30), p<0.001 ; \mathrm{UW}+\mathrm{L}(1.7 \pm 0.30)$ versus UW ( $3.0 \pm 0.40), p<0.001$; for 12 hours, $\mathrm{EC}+\mathrm{L}(2.6 \pm 0.20)$ versus $\mathrm{EC}(6.2 \pm 0.50), p<$ $0.001 ; \mathrm{UW}+\mathrm{L}(2.0 \pm 0.40)$ versus $\mathrm{UW}(4.2 \pm 0.40)$, $p<0.001$. Kf values were significantly lower for the $\mathrm{UW}+\mathrm{L}$ group than for the $\mathrm{EC}+\mathrm{L}$ group at the 12-hour storage time: $\mathrm{UW}+\mathrm{L}(2.0 \pm 0.40)$ versus $\mathrm{EC}+\mathrm{L}(2.6 \pm 0.20), p=0.009$. Kf values were significantly lower in the UW group than in the EC group at both storage times: for 6 hours, UW (3.0 \pm $0.40)$ versus EC $(3.9 \pm 0.3), p<0.001$; for 12 hours, UW $(4.2 \pm 0.40)$ versus EC $(6.2 \pm 0.50), p<0.001$.

\section{Discussion}

By evaluating the functional parameters of gas exchange and compliance and the experimental 
measurement of the Kf, this study demonstrates that adding LT to EC and UW preservation solutions improves the postischemic function of cold stored rat lungs. Edema, impaired gas exchange, and decreased compliance are hallmarks of ischemiareperfusion injury in lung transplantation and can lead to increased postoperative morbidity and mortality. Protective effects in lungs preserved in EC and UW solution supplemented with LT were manifested by decreased edema, better gas exchange capabilities, and better compliance as quantified by lower $\mathrm{Kf}$ values, higher $\mathrm{PO}_{2}$ values, lower $\mathrm{A}-\mathrm{aDO}_{2}$ values, and increased compliance, respectively.

Mast cells are inflammatory cells that can be activated by changes in cyclic nucleotide concentration, calcium influx, and immunoglobulin E-antibody complexes. ${ }^{13}$ They have also been shown to be activated by reperfusion in an ischemic dog lung model ${ }^{14}$ and most recently in a syngeneic rat transplant model. ${ }^{2}$ When activated, mast cells release a variety of vasoactive substances that cause smooth muscle contraction, increased vascular permeability, and neutrophil chemotaxis. The mechanism by which mast cells are activated by reperfusion is unclear, but their potential contribution to transplant preservation injury is increasingly apparent on the basis of recent studies. ${ }^{2,3}$

In our study, the probable mechanism by which LT exerted the observed protective effects was inhibition of mast cell degranulation. The concentration of LT $(10 \mu \mathrm{mol} / \mathrm{L})$ that was used is in the optimal range for preventing histamine release from isolated rat mast cells. ${ }^{4}$ This same concentration was also shown to inhibit mast cell degranulation and prevent reperfusion injury in our prior work in isolated rat hearts. ${ }^{11}$ As the effects of the substances released on mast cell degranulation are to increase vascular permeability (edema) and bronchial smooth muscle contraction, the decrease in these effects observed in lungs flushed and stored using LT-enhanced solutions can be attributed to the decrease in mast cell mediator release. Resident mast cells located in the pulmonary interstitium were the likely target of LT action, as it was added to the preservation solution and not to the reperfusion blood. Hydroxyl radicals, xanthine oxidase formation, and neutrophil chemotaxis are known to contribute to ischemia-reperfusion injury. ${ }^{7,8,15}$ Inasmuch as LT has been shown to be a substrate for the hydroxyl radical $^{5}$ and an inhibitor of xanthine oxidase ${ }^{6}$ and direct neutrophil chemotaxis, ${ }^{7}$ it could be interpreted that the observed beneficial effects in this study were derived from these alternative properties of LT. However,

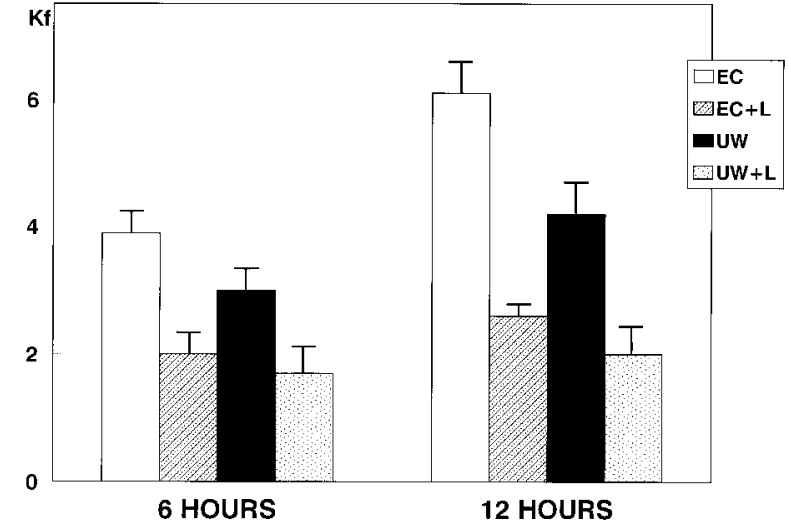

Fig. 4. Kf for all groups at 6 and 12 hours of storage. Kf was normalized to $100 \mathrm{gm}$ wet lung weight and expressed in milliliters per minute per milligrams of mercury per 100 gm. Significant comparisons at 6 hours were as follows: $\mathrm{EC}+\mathrm{L}$ versus EC, $p<0.001 ; \mathrm{UW}+\mathrm{L}$ versus $\mathrm{UW}, p<$ 0.001 ; UW versus EC, $p<0.001$. Significant comparisons at 12 hours were as follows: $\mathrm{EC}+\mathrm{L}$ versus $\mathrm{EC}, p<0.001$; $\mathrm{UW}+\mathrm{L}$ versus $\mathrm{UW}, p<0.001 ; \mathrm{UW}+\mathrm{L}$ versus $\mathrm{EC}+\mathrm{L}, p=$ 0.009 ; UW versus EC, $p<0.001$.

because of the dose used in this study, we believe that non-mast cell-mediated effects played a minor role, if any, in decreasing reperfusion injury. Fortyeight percent xanthine oxidase inhibition in vitro is achieved at a concentration 8 times higher $(80$ $\mu \mathrm{mol} / \mathrm{L}$ ) than was used, ${ }^{6}$ xanthine oxidase is inhibited in vivo at a concentration 100 times higher $(1000 \mu \mathrm{mol} / \mathrm{L}),{ }^{10}$ direct neutrophil chemotaxis is achieved in vitro at a concentration 25 times higher $(250 \mu \mathrm{mol} / \mathrm{L}){ }^{7}$ and hydroxyl radical scavenging is observed at a concentration 48 times higher (480 $\mu \mathrm{mol} / \mathrm{L}){ }^{5}$ Mast cell response to LT is biphasic; at low doses $(10$ to $50 \mu \mathrm{mol} / \mathrm{L})$ mediator release is inhibited and at higher doses (50 to $500 \mu \mathrm{mol} / \mathrm{L}$ ) mediator release is enhanced. ${ }^{16}$ It is possible that part of the beneficial effect afforded by LT was due to inhibition of indirect neutrophil chemotaxis resulting from the direct inhibition of mast cell degranulation; however, because of the low concentration of LT that was used, the majority of the protective effects were likely a consequence of mast cell degranulation inhibition. This hypothesis is also supported by results from our work in the rat cardiac model in which reperfusion was performed with an asanguineous crystalloid solution, thus eliminating circulating neutrophil chemotaxis as a possible contributor.

The data from this study support previous findings that UW is superior to EC for experimental 
lung preservation. ${ }^{17,18}$ The superiority of UW preservation was demonstrated by the improved function of lungs preserved with standard UW and $\mathrm{UW}+\mathrm{L}$ compared with lungs preserved with standard $\mathrm{EC}$ and $\mathrm{EC}+\mathrm{L}$. UW $+\mathrm{L}$-preserved lungs functioned better that $\mathrm{EC}+\mathrm{L}$-preserved lungs in most end-point categories at both 6 and 12 hours. UWpreserved lungs performed significantly better than EC-preserved lungs in all end-point categories at 12 hours of storage. The difference at the 6-hour storage time was represented by the significantly lower $\mathrm{Kf}$ in the UW group. Kf is known to be a sensitive indicator of changes in endothelial membrane integrity ${ }^{19}$ and thus the improved protection afforded by UW was demonstrated.

Although extrapolation from a rodent model to clinical human lung transplantation is always problematic, this study provides evidence that inhibition of resident mast cell degranulation decreases pulmonary reperfusion injury. Inasmuch as the human lung is known to contain an even greater inherent population of mast cells than is the rat, this study has potential clinical implications. The exact mechanism by which mast cells are activated by reperfusion remains unclear, however, and further study is required to fully describe their role in clinical reperfusion injury.

This study also indicates that EC and UW, the two most commonly used clinical lung preservation solutions, are not optimal because they were both significantly improved by adding LT. In the development of new lung preservation solutions, we believe there may be a benefit to considering the role of the mast cell in reperfusion injury and incorporating mast cell stabilizing compounds into the solutions.

\section{REFERENCES}

1. Bishop MJ, Chi EY, Su M, Cheney FW. Dimethylthiourea does not ameliorate lung reperfusion injury in dogs or rabbits. J Appl Physiol 1987;63:942-50.

2. Minani M, Nakahara K, Matasamura A, Mizuta T, Yoon H, Sakaguchi M, et al. Histamine release from pulmonary mast cells after lung transplantation in rats. J Heart Lung Transplant 1995;14:505-11.

3. Buvry A, Garbarg M, Dimitriadou V, Roulleau A, Newlands GFJ, Tavakole R, et al. Phenotypic and quantitative changes in mast cells after syngeneic unilateral lung transplant in the rat. Clin Sci 1996;91:319-27.

4. Johnson HG, Sheridan AQ. The characterization of lodoxamide, a very active inhibitor of mediator release, in animal and human models of asthma. Agents Actions 1986;3/4: 301-5.

5. Till GO, Guilds LS, Mahrougui M, Friedl HP, Trentz O,
Ward P. Role of xanthine oxidase in thermal injury of skin. Am J Pathol 1989;135:195-202.

6. White GJ. Inhibition of oxidative enzymes by anti-allergy drugs. Agents Actions 1981;11:503-9.

7. Veal CF Jr, Jackson RM, Brannen AL, Fulmer JD. Lodoxamide tromethamine prevents neutrophil accumulation in reexpansion pulmonary edema. J Card Pharmacol 1989;14: 227-32.

8. Jolly SR, Abrams GD, Romson JL, Baile MB, Lucchesi BR. Effects of lodoxamide on ischemic reperfused myocardium. J Cardiovasc Pharmacol 1982;4:441-8.

9. Ball TD, Lundy EF, Zelenock GB, D'Alecy LG. Effects of lodoxamide tromethamine on paraplegia that occurs after infrarenal aortic occlusion in the rabbit. J Vasc Surg 1987;6: 572-7.

10. Lynch MJ, Grum CM, Gallagher KP, Bolling SF, Deeb GM, Morganroth ML. Xanthine oxidase inhibition attenuates ischemic reperfusion lung injury. J Surg Res 1988;44:538-44.

11. Keller AM, Clancy RM, Barr ML, Marboe CC, Cannon PJ. Acute reoxygenation injury in the isolated rat heart: role of resident cardiac mast cells. Circ Res 1988;63:1044-52.

12. Drake R, Garr A, Taylor AE. Estimation of the filtration coefficient of pulmonary exchange vessels. Am J Physiol 1978;234:H266-74.

13. Dvorak AM, Peters SP, Sherman ES. Mast cells. In: Massory D, editor. Lung cell biology. New York: Marcell Dekker; 1989. p. $345-78$.

14. Su M, Chi EJ, Bishop MJ, Henderson WR Jr. Lung mast cells increase in number and degranulate during pulmonary artery occlusion/reperfusion injury in dogs. Am Rev Respir Dis 1993;147:448-56.

15. McCord JM. Oxygen derived free radicals in postischemic tissue injury. N Engl J Med 1985;312:159-63.

16. Johnson HG. New anti-allergy drugs-the lodoxamides. TIPS August 1980:343-5.

17. Xiong L, Mazmanian M, Chapelier AR, Reighner J, Weiss M, Dartevelle PG, et al. Lung preservation with EuroCollins, University of Wisconsin, Wallwork, and low-potassium-dextran solutions. Ann Thorac Surg 1994;58:845-50.

18. Aeba R, Kennan RJ, Hardesty RL, Yousem SA, Hamamoto I, Griffith R. University of Wisconsin solution for pulmonary preservation in a rat transplant model. Ann Thorac Surg 1992;53:240-6.

19. Drake RE, Laine GA. Pulmonary microvascular permeability to fluid and macromolecules. J Appl Physiol 1988;64:487-501.

\section{Discussion}

Dr. Paul F. Waters (Los Angeles, Calif.). I have a number of questions. First, is EC or UW solution better in this model? From your data, it appears that UW solution is better. I notice that your UW solution contains steroid. Do you think that has any effect on the mast cells and maybe could account for that difference?

Dr. Barr. That is a good question, but I do not have an answer. We just tried to imitate what we would normally do in the clinical scenario of adding dexamethasone and insulin just as is recommended. In terms of your observation about UW being better than EC, other groups have shown that, too, and some of us believe that is the case clinically. However, in every experiment that we have done in our laboratory comparing EC and UW, either with large animals or with small animals, UW was supe- 
rior. UW was statistically superior to unmodified EC solution every time, independent of the issue of mast cells. I do not know whether steroids play a big role or not.

Dr. Waters. Why did you use syngenetic blood instead of the donor animal's blood?

Dr. Barr. Because this is not a recirculating model, there would be insufficient blood from the donor animal. We used blood from another Lewis rat so that we could eliminate the issue of an allogeneic response and just have pure reperfusion injury.

Dr. Waters. Was the temperature of the perfused blood controlled?

Dr. Barr. Yes, it was.

Dr. Waters. It would have been tempting to look at the histologic features. Did you think about doing that?

Dr. Barr. In fact, we did that. The issue of how well histologic characteristics correlate is a matter of controversy in preservation research. Even though UW solution has worked better in animal and human studies, the histologic features of the endomyocardial biopsy specimen, for instance in heart preservation, look worse. We did do electron microscopic studies on some of these samples and could not see any differences. Laboratories in addition to ours have not found differences in function as it relates to histologic features. However, we did not include this material in our report because we observed no difference between the two groups.
Dr. Waters. My final comment is a more fundamental question. A number of preservation solutions have been fantastic in the rat model, but those results have not persisted when tested in larger animals and ultimately patients. Solutions in the Japanese work, LPD, for instance, have worked well experimentally but have not worked in human beings. Do you think that the rat is a relevant model for lung preservation?

Dr. Barr. When I used the word validated, I actually meant in regard to our parameters and Kf. I agree with you completely about the relevance of studies in rats. We do need to take this to a larger animal model, ideally primates, before doing a study in human beings. In fact, our next set of experiments is in primates.

Dr. Waters. Did you consider implanting the lung in this study? Putting the lung into a rat would be more physiologic and perhaps change what we would observe.

Dr. Barr. We did not do that in this experiment. The reason is that we believe very strongly in the $\mathrm{Kf}$ as a measurement for detecting changes between experimental groups. Groups that have compared UW versus EC with an implanted graft have shown results similar to those we just showed, but they were not able to measure the same parameters.

\section{Availability of Journal back issues}

As a service to our subscribers, copies of back issues of The Journal of Thoracic and Cardiovascular Surgery for the preceding 5 years are maintained and are available for purchase from Mosby at a cost of $\$ 16.00$ per issue until inventory is depleted. The following quantity discounts are available: $25 \%$ off on quantities of 12 to 23, and one third off on quantities of 24 or more. Please write to Mosby, Inc., Subscription Services, 11830 Westline Industrial Drive, St. Louis MO 63146-3318, or call 800-453-4351 or 314-453-4351 for information on availability of particular issues. If unavailable from the publisher, photocopies of complete issues may be purchased from UMI, 300 N. Zeeb Rd., Ann Arbor, MI 48106, 313-761-4700. 